Scientific paper

\title{
Spectrophotometric Studies of 4-[N'-(4-Imino-2-oxo-thiazolidin-5-ylidene)-hydrazino]- benzenesulfonic acid as a Reagent for the Determination of Palladium
}

\author{
Lesya Lozynska, ${ }^{1, *}$ Oleksandr Tymoshuk ${ }^{1}$ and Taras Chaban ${ }^{2}$ \\ ${ }^{1}$ Department of Chemistry, Ivan Franko National University of Lviv, Kyryla i Mefodiya Str., 6, 79005 Lviv, Ukraine; \\ ${ }^{2}$ Faculty of Pharmacy, Danylo Halytsky Lviv National Medical University, Pekarska Str., 69, 79010 Lviv, Ukraine \\ *Corresponding author: E-mail: l_lozynska@ukr.net
}

Received: 30-07-2014

\begin{abstract}
The spectrophotometric behavior of a new, first-time synthesized reagent - 4-[N'-(4-imino-2-oxo-thiazolidin-5-ylidene)-hydrazino]-benzenesulfonic acid (ITHBA), has been investigated. A simple, rapid, accurate, selective and sensitive method for the spectrophotometric determination of Pd(II) ions using this reagent was developed. The optimal conditions for the formation of the complexes were found. The molar absorptivity at $\lambda=438 \mathrm{~nm}$ is $7.5 \times 10^{3} \mathrm{~L} \mathrm{~mol}^{-1} \mathrm{~cm}^{-1}$, and Beer's law is observed for the concentrations ranging from $0.2-2.2 \mu \mathrm{g} \mathrm{mL} \mathrm{L}^{-1} \mathrm{Pd}(\mathrm{II})$. The effects of extraneous ions were investigated. The method proved to be successful in determination of palladium in the intermetallides and resistor. The accuracy of spectrophotometric palladium assay in real objects with 4-[ $N^{\prime}$-(4-imino-2-oxo-thiazolidin-5-ylidene)hydrazino]-benzenesulfonic acid has been confirmed by voltammetric or atomic absorption spectroscopy method.
\end{abstract}

Keywords: Palladium(II); 4-[N'-(4-imino-2-oxo-thiazolidin-5-ylidene)-hydrazino]-benzenesulfonic acid; spectrophotometry; azolidones; intermetallides; resistor.

\section{Introduction}

Palladium is widely used in various fields, especially in catalysis, petroleum, electronics. Owing to its corrosion resistant nature and alloying ability, palladium and its alloys are used in dental and medicinal devices, and in jewelry manufacture. ${ }^{1,2}$ The increasing area of the palladium applications stimulates the development of simple and rapid methods for the quantitative determination of palladium(II). For the determination of palladium at micro levels, several analytical techniques such as atomic absorption spectrometry, inductive coupled plasma atomic emission, ion chromatography, X-ray fluorescence spectrometry, and neutron activation are used. However, spectrophotometric methods have gained popularity for palladium determination as advantageous due to their simplicity and low operating costs. A wide variety of spectrophotometric reagents, such as azo dyes, rhodanine derivatives, porphyrin ligands, thiourea derivatives, 8-aminoquinoline derivatives and nitroso dye have been developed for the deter- mination of palladium. ${ }^{3-20}$ Many of these reagents have some disadvantages, such as low sensitivity, poor selectivity, durability, extraction, necessity to use high temperature to promote the complexation reaction.

In our previous studies the interaction of $\mathrm{Pd}(\mathrm{II})$, $\mathrm{Rh}(\mathrm{III}), \mathrm{Pt}(\mathrm{IV}), \mathrm{Ru}(\mathrm{IV}), \mathrm{Ir}(\mathrm{IV})$ ions with a new reagent 5-hydroxyimino-4-imino-1,3-thiazolidin-2-one, which belongs to the class of azolidones, was investigated. Spectrophotometric methods for determination of platinum metals with this reagent were developed. ${ }^{21-24}$

Azolidones as a new class of organic compounds were discovered in the middle of the $20^{\text {th }}$ century. ${ }^{25}$ These reagents are widely used in medicine, due to their wide range of biological activity. ${ }^{26,27}$ In this work, we investigated the interaction of palladium(II) ions with first-time synthesized reagent - 4-[ $N^{\prime}$-(4-imino-2-oxo-thiazolidin5-ylidene)-hydrazino]-benzenesulfonic acid (ITHBA). This reagent also belongs to the class of azolidones and has a similar structure to 5-hydroxyimino-4-imino-1,3thiazolidin-2-one. 


\section{Experimental}

\section{1. Apparatus}

Absorption spectra were obtained using 108 UV/ULAB spectrophotometer and $1.0 \mathrm{~cm}$ quartz cells. Absorption was also measured at KFK-3 using $5.0 \mathrm{~cm}$ glass cells. All absorbance measurements were performed at $\sim 20^{\circ} \mathrm{C}$.

Voltammetric measurements were performed using an oscillopolarograph CLA-03 with a digital setup equipped with a computer and a three-electrode cell using linear potential sweep. A dropping mercury electrode, a platinum electrode and a saturated calomel electrode served as and indicator, auxiliary, and reference electrodes, respectively.

Atomic absorption measurements were performed using the atomic absorption spectrophotometer AAS-1N at $\lambda=246.5 \mathrm{~nm}$ in the propane-butane-air flame. The monochromatic radiation source was a hollow-cathode lamp produced by "Narva".

${ }^{1} \mathrm{H}$ NMR spectra of compounds dissolved in DMSO- $\mathrm{d}_{6}$ were registered on the spectrometer Bruker Avance (400 MHz), internal reference of TMS.

The $\mathrm{pH}$ measurements were carried out with $\mathrm{pH}$-meter model $\mathrm{pH}-150 \mathrm{M}$ equipped with a combination glass electrode.

\section{2. Reagents}

All aqueous solutions for experiments have been prepared using distillated water. All chemicals used in the research were of analytical grade.

The stock solution of $\mathrm{Pd}(\mathrm{II})$ was prepared by dissolving metallic palladium $(99.999 \%)$ in a mixture of concentrated $\mathrm{HNO}_{3}$ and $\mathrm{HCl}$ (1:3). The standard working $\mathrm{Pd}(\mathrm{II})$ solutions were prepared by diluting an aliquot of palladium(II) stock solution in $1.0 \mathrm{~mol} \mathrm{~L}^{-1} \mathrm{HCl}$.

The solution of 4-[N'-(4-imino-2-oxo-thiazolidin-5ylidene)-hydrazino]-benzenesulfonic acid was prepared by dissolving the exact mass of the reagent in water. ITHBA was synthesized by the following procedure: in a $100 \mathrm{ml}$ round-bottomed flask, fitted with a mechanical stirrer $1.16 \mathrm{~g}(10 \mathrm{mmol}) 4$-iminotiazolidone- $2^{28}$ and $4.0 \mathrm{~g}$ of sodium acetate in $80 \mathrm{~mL}$ of acetic acid were placed. The mixture was cooled till $0{ }^{\circ} \mathrm{C}$ and the diazonium salt (prepared by using $2.1 \mathrm{~g} \mathrm{(10} \mathrm{mmol)} \mathrm{4-aminobenzenesul-}$ fonic acid) was added. The mixture was left for $12-18 \mathrm{~h}$, and then was poured into $200-300 \mathrm{~mL}$ of water. The precipitate was filtered, washed with water, and dried at $60{ }^{\circ} \mathrm{C}$. Yield $85 \%$. ${ }^{1} \mathrm{H}$ NMR (400 MHz, DMSO-d6; $\delta$, ppm): $7.40 \mathrm{~d}\left(J=6.4 \mathrm{~Hz}, 2 \mathrm{H}, \mathrm{C}_{6} \mathrm{H}_{4}\right), 7.51 \mathrm{~d}(J=6.4 \mathrm{~Hz}$, $\left.2 \mathrm{H}, \mathrm{C}_{6} \mathrm{H}_{4}\right), 8.95 \mathrm{~s}(\mathrm{H}, \mathrm{NH}), 9.18 \mathrm{~s}(\mathrm{H}, \mathrm{NH}), 10.42 \mathrm{~s}(\mathrm{H}$, $\mathrm{NH})$. The purity of reagent is $100 \%$, which was determined by chromatography-mass spectrometry.

The solutions of $\mathrm{Na}_{2} \mathrm{~B}_{4} \mathrm{O}_{7}, \mathrm{NaOH}$ were prepared by dissolving of appropriate amount of $\mathrm{Na}_{2} \mathrm{~B}_{4} \mathrm{O}_{7}, \mathrm{NaOH}$ in water. The $\mathrm{HCl}$ solution was prepared by dilution of concentrated $\mathrm{HCl}$. The universal buffer solutions (UBS) were made by mixing solutions of phosphoric, boric and acetic acids. $^{29}$

\section{3. Procedure}

\section{Protolytic equilibria experiment}

$1.0 \mathrm{~mL}$ of $1.0 \times 10^{-3} \mathrm{~mol} \mathrm{~L}^{-1}$ ITHBA, $2.0 \mathrm{~mL}$ universal buffer $\left(1.5 \mathrm{~mol} \mathrm{~L}^{-1}\right)$, and $1.25 \mathrm{~mL}$ of $2.0 \mathrm{~mol} \mathrm{~L}^{-1}$ $\mathrm{NaCl}$ were placed in a $25.0 \mathrm{~mL}$ standard flask and the distilled water was added to a total volume of $\sim 15-20 \mathrm{~mL}$. Then the $\mathrm{pH}$ was adjusted by means of $4.0 \mathrm{~mol} \mathrm{~L}^{-1} \mathrm{NaOH}$ addition $(\mathrm{pH}=2.0-12.0)$. Next, distilled water was added to complete the volume and its absorption spectrum was measured. For $\mathrm{pH}=1.0$, the solution was prepared as follows: $1.0 \mathrm{~mL}$ of $1.0 \times 10^{-3} \mathrm{~mol} \mathrm{~L}^{-1}$ ITHBA, $1.25 \mathrm{~mL}$ of $2.0 \mathrm{~mol} \mathrm{~L}^{-1} \mathrm{NaCl}$ solutions were poured into $25.0 \mathrm{~mL}$ flask and the distilled water was added to a total volume of $\sim 15-20 \mathrm{~mL}$; then the $\mathrm{pH}$ was adjusted by means of $6.0 \mathrm{~mol} \mathrm{~L}^{-1} \mathrm{HCl}$ addition; after that, distilled water was added to complete the volume and its absorption spectrum was measured.

\section{Interaction of $\mathrm{Pd}(\mathrm{II})$ with ITHBA in water solution}

The $1.0 \mathrm{~mL}$ of $1.0 \times 10^{-3} \mathrm{~mol} \mathrm{~L}^{-1}$ ITHBA, $1.11 \mathrm{~mL}$ of $4.5 \times 10^{-4} \mathrm{~mol} \mathrm{~L}^{-1} \mathrm{Pd}(\mathrm{II})$ and $1.25 \mathrm{~mL}$ of $2.0 \mathrm{~mol} \mathrm{~L}^{-1}$ $\mathrm{NaCl}$ were put into $25.0 \mathrm{~mL}$ flasks and the distilled water was added to a total volume of $\sim 15-20 \mathrm{~mL}$. Then the $\mathrm{pH}$ was adjusted by means of addition of $\mathrm{NaOH}$ and $\mathrm{HCl}$ diluted solutions. After that, distilled water was added to complete the volume and its absorption spectrum was measured.

\section{Influence of concentration and nature of the anion}

The $1.0 \mathrm{~mL}$ of $1.0 \times 10^{-3} \mathrm{~mol} \mathrm{~L}^{-1}$ ITHBA, $1.11 \mathrm{~mL}$ of $4.5 \times 10^{-4} \mathrm{~mol} \mathrm{~L}^{-1} \mathrm{Pd}(\mathrm{II})$, and the solution of sodium salt with the studied anion were put into $25.0 \mathrm{~mL}$ flasks and the distilled water was added to a total volume of $\sim 15-20 \mathrm{~mL}$. Then the $\mathrm{pH}(\mathrm{pH}=8.0)$ was adjusted by means of addition of $\mathrm{HCl}$ and $\mathrm{NaOH}$ diluted solutions. After that, distilled water was added to complete the volume, and the absorbance of the solution was measured relatively to a blank solution at $438 \mathrm{~nm}$. The blank solution contained all the components of the sample with the exception of $\mathrm{Pd}(\mathrm{II})$.

\section{Effect of extraneous ions}

The $2.5 \mathrm{~mL}$ of $1.0 \times 10^{-3} \mathrm{~mol} \mathrm{~L}^{-1}$ ITHBA, $0.5 \mathrm{~mL}$ of $4.5 \times 10^{-4} \mathrm{~mol} \mathrm{~L}^{-1} \mathrm{Pd}(\mathrm{II}), 12.5 \mathrm{~mL}$ of $0.1 \mathrm{~mol} \mathrm{~L}^{-1}$ $\mathrm{Na}_{2} \mathrm{~B}_{4} \mathrm{O}_{7}$, and appropriate volume of the solution of foreign ion, were put into $25.0 \mathrm{~mL}$ flasks and the distilled water was added to a total volume of $\sim 15-20 \mathrm{~mL}$. Then the $\mathrm{pH}$ was adjusted by means of addition of $\mathrm{HCl}$ and $\mathrm{Na}-$ $\mathrm{OH}$ diluted solutions $(\mathrm{pH}=8.0)$. After that, distilled water was added to complete the volume, and the absorbance of 
the solution was measured relative to a blank solution at $438 \mathrm{~nm}$. The blank solution contained all the components of the sample with the exception of Pd(II).

\section{The procedure of palladium assay in the intermetallides}

The samples of intermetallides $(0.1-0.2 \mathrm{~g}$ of the intermetallic alloy) were dissolved in $10-20 \mathrm{~mL}$ of a mixture of concentrated $\mathrm{HCl}$ and $\mathrm{HNO}_{3}$ (3:1). The resulting mixture was boiled in a beaker in a sand bath for 1-2 h. The dry residue was dissolved in a $2.5 \mathrm{~mol} \mathrm{~L}^{-1} \mathrm{HCl}$ solution and transferred into a $100.0 \mathrm{~mL}$ volumetric flask. The working solution was prepared by diluting an aliquot of the stock solution 10 times by $1.0 \mathrm{~mol} \mathrm{~L}^{-1} \mathrm{HCl}$. For palladium determination $0.5-1.0 \mathrm{~mL}$ of analytes' aliquots has been taken and undergone the proper analytical procedure according to the following scheme. The necessary quantities of solutions of ITHBA, the analytes' aliquots and sodium tetraborate were placed into a $25.0 \mathrm{~mL}$ volumetric flask and the distilled water was added to a total volume of $\sim 15-20 \mathrm{~mL}$. Then the $\mathrm{pH}$ was adjusted by means of addition of $\mathrm{NaOH}$ and $\mathrm{HCl}$ diluted solutions. After that, distilled water was added to complete the volume and the absorbance measurement was carried out against blank solution at $438 \mathrm{~nm}$ in $5.0 \mathrm{~cm}$ cells. The palladium content was evaluated using the method of a normal calibration curve (all tests were performed at the alpha level of $5 \%$; the number of individual measurements $n$ was 3; confidence limits were calculated as means $\pm \mathrm{St}_{\alpha} / \sqrt{ } \mathrm{n}$, where $\mathrm{S}$ is a standard deviation and $\mathrm{t}_{\alpha}=4.30$ ).

\section{The procedure of palladium assay in the resistor}

All parts of the resistor, containing platinum group elements, have been transferred into a beaker and dissolved in $20 \mathrm{~mL}$ of a mixture of concentrated $\mathrm{HCl}$ and $\mathrm{HNO}_{3}$ (3:1) by heating on a sand bath during $1 \mathrm{~h}$ with further decantation. Obtained palladium(II) was transferred into chloride form by means of evaporation of the solution into wet salts and adding $10.0 \mathrm{~mL}$ of concentrated $\mathrm{HCl}$ until nitrogen oxides stopped discharging. Then the content of the beaker was quantitatively transferred into a $50.0 \mathrm{~mL}$ volumetric flask and brought to the mark with distilled water. The working solution was prepared by diluting stock solution 10 times with 1.0 mol L ${ }^{-1}$ hydroch- loric acid. For palladium determination $0.5 \mathrm{~mL}$ of analytes' aliquots has been taken and undergone the proper analytical procedure according to the following scheme. The necessary quantities of solutions of ITHBA, the analytes' aliquots and sodium tetraborate were placed into a $25.0 \mathrm{~mL}$ volumetric flask and distilled water was added to a total volume of $\sim 15-20 \mathrm{~mL}$. Then the $\mathrm{pH}$ was adjusted by means of addition of $\mathrm{NaOH}$ and $\mathrm{HCl}$ diluted solutions. After that, distilled water was added to complete the volume and the absorbance measurement was carried out against blank solution at $438 \mathrm{~nm}$ in $5.0 \mathrm{~cm}$ cells. The palladium content was evaluated using the method of a normal calibration curve (all tests were performed at the alpha level of $5 \%$; the number of individual measurements $n$ was 3 ; confidence limits were calculated as means $\pm \mathrm{St}_{\alpha} / \sqrt{\mathrm{n}}$, where $\mathrm{S}$ is a standard deviation and $\left.\mathrm{t}_{\alpha}=4.30\right)$.

\section{Results and Discussion}

\section{1. Protolytic Equilibria of ITHBA in Water Medium}

The analitical reagent, 4-[N'-(4-imino-2-oxo-thiazolidin-5-ylidene)-hydrazino]-benzenesulfonic acid, was prepared by azo coupling reaction of 4-iminothiazolidin2-one with diazotized sulfanilic acid (scheme 1):

It was supposed that 4-(4-imino-2-oxo-thiazolidin5-ylazo)-benzenesulfonic acid (B) or 4-(4-amino-2-oxo2,3-dihydrothiazol-5-ylazo)-benzenesulfonic acid (C) has formed, but from NMR spectroscopy it was apparent that the prepared compound is a tautomeric form $\mathbf{A}$ (scheme $2)$. In the ${ }^{1} \mathrm{H}$ NMR spectra there are free singlets ( $\delta: 8.95$. ppm , $9.18 \mathrm{ppm}$ and $10.42 \mathrm{ppm}$ ) belonging to an $\mathrm{N}-\mathrm{H}$ groups of tautomere $\mathbf{A}$.

We investigated the spectrophotometric characteristics of this reagent. Absorption maximum of the ITHBA depends on $\mathrm{pH}$ (Fig. 1). At $\mathrm{pH}=1.0-9.0$ two absorption maxima are observed at $\lambda=256 \mathrm{~nm}$ and $\lambda=382 \mathrm{~nm}$ ( $\mathrm{pH}=1.0 \lambda=390 \mathrm{~nm}), \mathrm{pH}=10.0-$ three absorption bands: $\lambda=256 \mathrm{~nm}, \lambda=382 \mathrm{~nm}$ and $\lambda=460 \mathrm{~nm}$, $\mathrm{pH}=11.0: \lambda=256 \mathrm{~nm}, \lambda=286 \mathrm{~nm}, \lambda=382 \mathrm{~nm}$ and $\lambda=460 \mathrm{~nm}, \mathrm{pH}=12.0: \lambda=250 \mathrm{~nm}, \lambda=286 \mathrm{~nm}$ and<smiles>[X][N+]([X])([O-])c1ccc(S(=O)(=O)O)cc1</smiles>

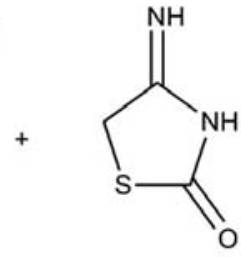

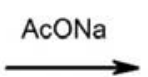

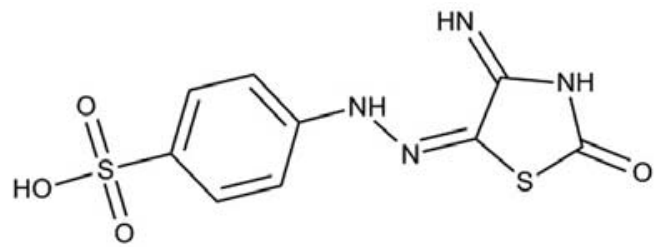

$$
X^{-}=\mathrm{Cl}^{-}, \mathrm{HSO}_{4}{ }^{-}
$$

Scheme 1. Synthesis of 4-[N'-(4-Imino-2-oxo-thiazolidin-5-ylidene)-hydrazino]-benzenesulfonic acid 
<smiles>N=C1NC(=O)S/C1=N\Nc1ccc(S(=O)(=O)O)cc1</smiles>

Scheme 2. Tautomeric forms of ITHBA

$\lambda=460 \mathrm{~nm}$. Beer's law is obeyed at $256 \mathrm{~nm}$ and $382 \mathrm{~nm}$ $(\mathrm{pH}=5.0)$ over a wide concentration range (Fig. 2). The average effective values of molar absorption coefficients at $\lambda=256 \mathrm{~nm}$ is $1.4 \times 10^{4} \mathrm{~L} \mathrm{~mol}^{-1} \mathrm{~cm}^{-1}$, and at $\lambda=$ $382 \mathrm{~nm}-2.5 \times 10^{4} \mathrm{~L} \mathrm{~mol}^{-1} \mathrm{~cm}^{-1}$.

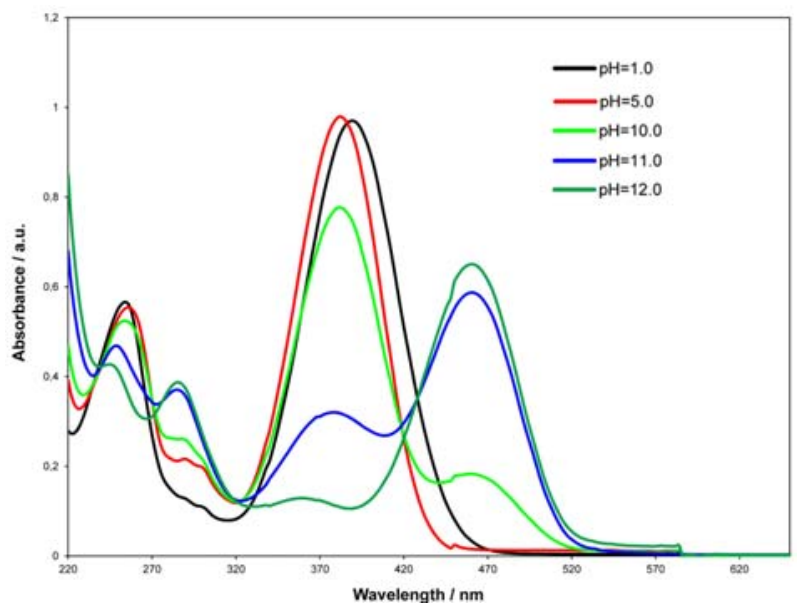

Fig. 1. Absorbance spectra of ITHBA at different $\mathrm{pH}$

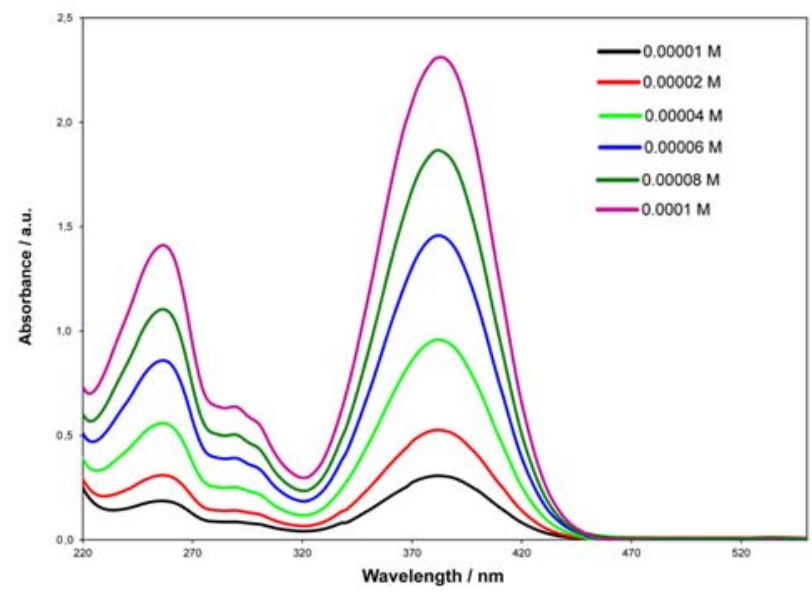

Fig. 2. Absorbance spectra of ITHBA of different molar concentration

\section{2. Investigation of the Interaction of $P d(I I)$ with ITHBA in Water Solution}

The ion of Pd(II) forms with ITHBA a yellow complex. Fig. 3 represents absorbance spectra of the dye solution and Pd(II)-ITHBA complex-compound. As seen from the absorption spectra, the absorption maximum of the complex is observed at $382 \mathrm{~nm}$. It is in the same wavelength area as the reagent, but compound of $\mathrm{Pd}(\mathrm{II})$ with ITHBA is characterized by the shoulder within the wavelength range of $420-550 \mathrm{~nm}$. According to Fig. 3, the investigation of the interaction between $\mathrm{Pd}(\mathrm{II})$ ions and ITHBA was performed at $\lambda=438 \mathrm{~nm}$. There is virtually no absorption of the reagent and the maximum increases in the value of shoulder. It should be noted that ions of $\mathrm{Pt}(\mathrm{IV}), \mathrm{Rh}(\mathrm{III}), \operatorname{Ir}(\mathrm{IV})$ and $\mathrm{Ru}(\mathrm{IV})$ do not interact with ITHBA.

To establish the optimal condition for complexation, we investigated the influence of acidity on the yield of complex compounds Pd(II)-ITHBA (Fig. 4). The complex is formed over a wide range of $\mathrm{pH}$. The maximum yield of $\mathrm{Pd}(\mathrm{II})$-ITHBA coloured compound was achieved in the range of $\mathrm{pH}=7.6-8.3$ against sodium

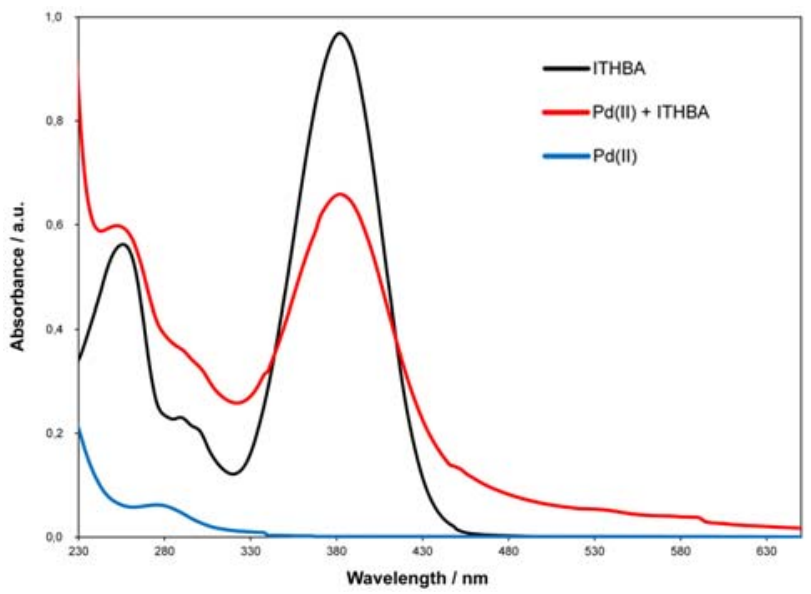

Fig. 3. Absorbance spectra of reagent, Pd(II) and complex Pd(II) with ITHBA 


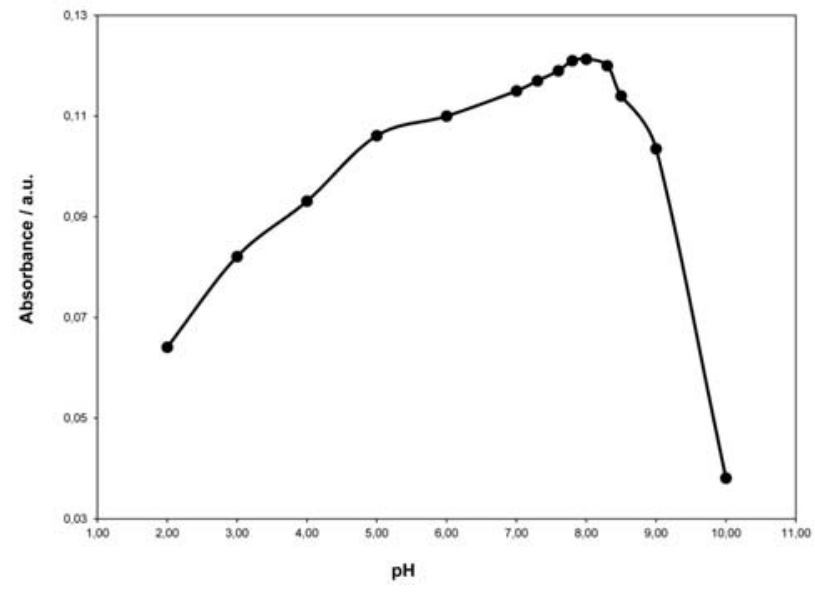

Fig. 4. Effect of acidity on the maximum yield of $\mathrm{Pd}(\mathrm{II})$ with ITHBA colored complex

chloride as a background. For further research, we chose $\mathrm{pH}=8.0$.

To select the medium in order to create the constant ionic strength the effect of the concentration and nature of anions of sodium salts on the interaction of $\mathrm{Pd}(\mathrm{II})$ with ITHBA was researched. In general, the nature of anion has small effect on the photometric characteristics of the complex. The $\mathrm{Cl}^{-}, \mathrm{CH}_{3} \mathrm{COO}^{-}, \mathrm{SO}_{4}{ }^{2-}, \mathrm{NO}_{3}^{-}-$have almost no effect on the value of the optical density; $\mathrm{PO}_{4}{ }^{3-}-$ at first increases and later decreases the yield of the complex. As the reaction medium, we chose a solution of sodium tetraborate, because the presence of $0.05 \mathrm{~mol} \mathrm{~L}^{-1}$ solution of $\mathrm{Na}_{2} \mathrm{~B}_{4} \mathrm{O}_{7}$ slightly increases the yield of the complex and improves the rapidity of the method.

To establish the optimal conditions for the photometric reaction, we examined the effect of standing time at room temperature and heating time in the boiling water bath $\left(\sim 98^{\circ} \mathrm{C}\right)$ on the yield of the complex. The compound $\mathrm{Pd}(\mathrm{II})$-ITHBA is formed at room temperature, and heating only reduces the magnitude of the analytical signal. The absorbance values remain virtually unchanged for $72 \mathrm{~h}$ during storage of the obtained product solution.

Using the mole-ratio method and the method of continuous variations, the correlation between the components in the reaction system was established. The results are illustrated in Fig. 5 and 6. The calculations indi-

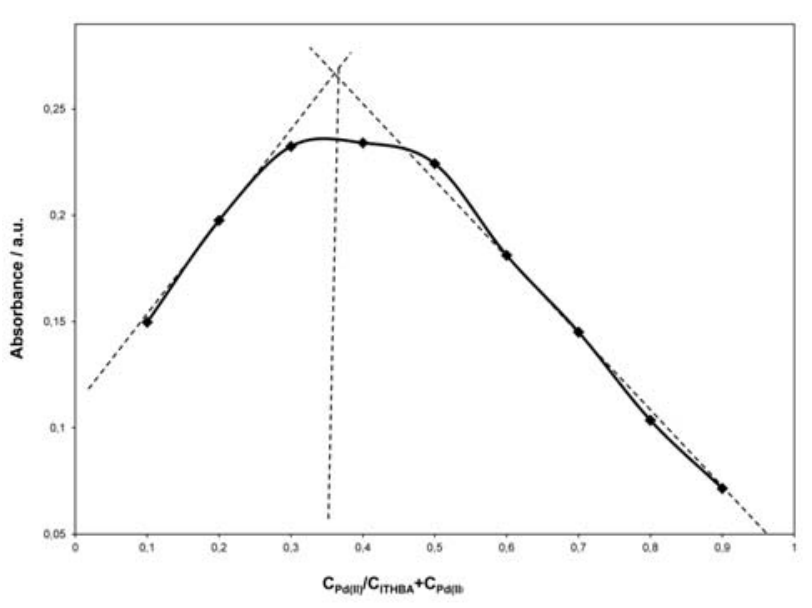

Fig. 5. The method of continuous variations

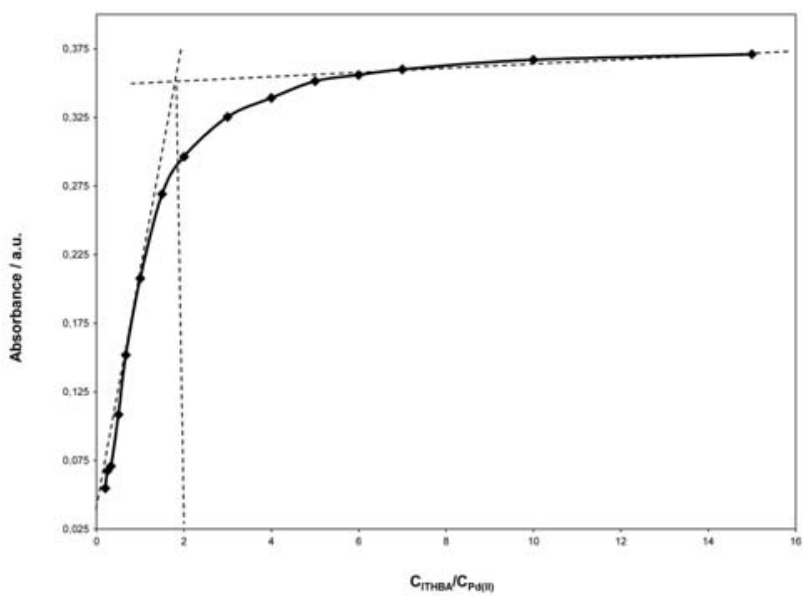

Fig. 6. The mole-ratio method

cate the formation of the complex with a ratio of components Pd(II):ITHBA $=1: 2$. It was found that 5-fold excess of the reagent is required for full colour development. The value of effective molar absorption coefficients is $7.5 \times 10^{3} \mathrm{~L} \mathrm{~mol}^{-1} \mathrm{~cm}^{-1}$; conditional stability constants is $7.9 \times 10^{10}$.

After analyzing the experimental data and literature sources it can be assumed that the palladium ions interact with ITHBA as shown in scheme 3 .

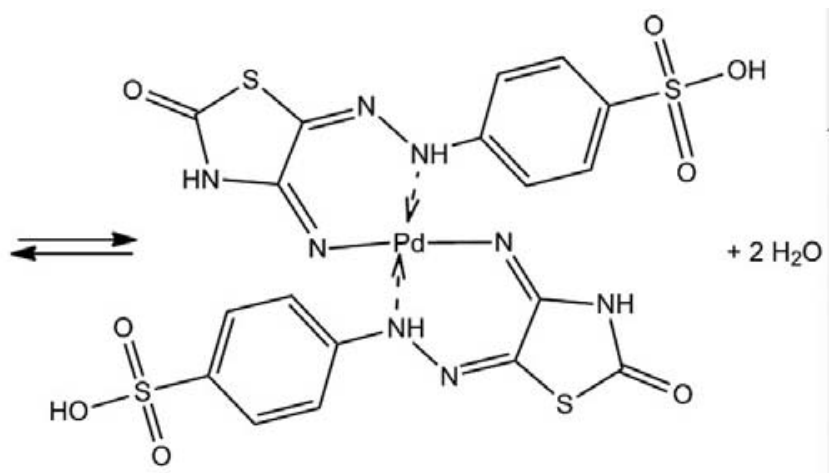

Scheme 3. Proposed reaction of Pd-ITHBA complex formation 
It has been established that the magnitude of the analytical signal in determining Pd(II) with ITHBA linearly depends on the concentration of metal in the solution. The metrological characteristics of spectrophotometric determination of palladium(II) with ITHBA are given in table 1.

Table 1. The metrological characteristics of spectrophotometric determination of the $\mathrm{Pd}(\mathrm{II})$ with ITHBA $(\mathrm{C}(\mathrm{ITHBA})=$ $1.0 \times 10^{-4} \mathrm{~mol} \mathrm{~L}^{-1} ; \mathrm{C}\left(\mathrm{Na}_{2} \mathrm{~B}_{4} \mathrm{O}_{7}\right)=0.05 \mathrm{~mol} \mathrm{~L}^{-1} ; \mathrm{pH}=8.0$; $\lambda=438 \mathrm{~nm} ; l=5.0 \mathrm{~cm} ; n=5 ; \mathrm{P}=0.95$ )

\begin{tabular}{lc}
\hline Characteristic & Value \\
\hline Linearity range, $\mathrm{C}_{\mathrm{Pd}(\mathrm{II})}, \mu \mathrm{g} \mathrm{mL}$ & $0.2-2.2$ \\
Calibration equation, $\mathrm{C}_{\mathrm{Pd}(\mathrm{II})}, \mu \mathrm{g} \mathrm{mL} \mathrm{mL}^{-1}$ & $\Delta \mathrm{A}=0.03+0.27 \times \mathrm{C}$ \\
Limit of detection, $\mathrm{C}_{\mathrm{Pd}(\mathrm{II})}, \mu \mathrm{g} \mathrm{mL}$ & 0.07 \\
Limit of determination, $\mathrm{C}_{\mathrm{Pd}(\mathrm{II})}, \mu \mathrm{g} \mathrm{mL} \mathrm{m}^{-1}$ & 0.2 \\
Correlation coefficient, $\mathrm{R}$ & 0.9997 \\
\hline
\end{tabular}

\section{3. Investigation of the Effect of Foreign Ions}

The selectivity of developed technique was tested in determination of palladium(II) in the presence of platinum group elements, alkali-earth, heavy metals and other metals as well as some anions. The results of the selectivity investigation are shown in table 2 . The technique is characterized by good selectivity towards many metals, such as $\mathrm{Pt}(\mathrm{IV}), \mathrm{Rh}(\mathrm{III}), \mathrm{Ni}(\mathrm{II}), \mathrm{Co}(\mathrm{II}), \mathrm{Cu}(\mathrm{II}), \mathrm{Ag}(\mathrm{I})$ and other metals, which often occur in the Pd-containing objects of study. The anions, which were researched also did not interfere much, and, therefore, they can be used to mask certain metals to improve selectivity.

\section{4. Determination of Palladium in Model Systems and Real Objects}

The accuracy of palladium(II) spectrophotometric determination with ITHBA has been tested using the "in-

Table 2. Tolerance ratios of extraneous ions during the spectrophotometric determination of $\mathrm{Pd}(\mathrm{II})$ in the presence of 4-[ $N^{\prime}$-(4-imino-2-oxo-thiazolidin-5-ylidene)-hydrazino]-benzenesulfonic acid (C(ITHBA) $=1.0 \times 10^{-4} \mathrm{~mol} \mathrm{~L}^{-1}$;

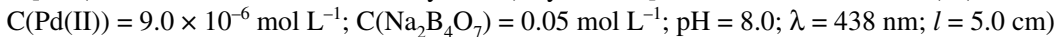

\begin{tabular}{cccccc}
\hline Extraneous ion & $\mathbf{C}_{\mathbf{P d}(\text { II) }}: \mathbf{C}_{\text {ion }}$ & Extraneous ion & $\mathbf{C}_{\mathbf{P d}(\mathrm{II})}: \mathbf{C}_{\text {ion }}$ & Extraneous ion & $\mathbf{C}_{\mathbf{P d}(\mathrm{II})} \mathbf{C}_{\text {ion }}$ \\
\hline $\mathrm{Ru}(\mathrm{IV})$ & $1: 1$ & $\mathrm{Cu}(\mathrm{II})$ & $1: 50$ & $\mathrm{Ca}(\mathrm{II})$ & $1:>200$ \\
$\mathrm{Ir}(\mathrm{IV})$ & $1: 2$ & $\mathrm{~Pb}(\mathrm{II})$ & $1:>200$ & $\mathrm{Mg}(\mathrm{II})$ & $1:>200$ \\
$\mathrm{Rh}(\mathrm{III})$ & $1: 15$ & $\mathrm{Cd}(\mathrm{II})$ & $1:>200$ & $\mathrm{C}_{2} \mathrm{O}_{4}{ }^{2-}$ & $1:>200$ \\
$\mathrm{Pt}(\mathrm{IV})$ & $1: 15$ & $\mathrm{Zn}(\mathrm{II})$ & $1: 40$ & $\mathrm{~F}^{-}$ & $1:>200$ \\
$\mathrm{Au}(\mathrm{III})$ & $1: 10$ & $\mathrm{Hg}(\mathrm{II})$ & $1: 15$ & $\mathrm{SiO}_{3}{ }^{2-}$ & $1:>200$ \\
$\mathrm{Ni}(\mathrm{II})$ & $1:>200$ & $\mathrm{Ga}(\mathrm{III})$ & $1: 50$ & $\mathrm{EDTA}^{-}$ & $1: 25$ \\
$\mathrm{Co}(\mathrm{II})$ & $1:>200$ & $\mathrm{Sn}(\mathrm{II})$ & $1: 40$ & $\mathrm{Sal}^{-}$ & $1:>200$ \\
$\mathrm{Ag}(\mathrm{I})$ & $1: 40$ & $\mathrm{Yb}(\mathrm{III})$ & $1: 15$ & $\mathrm{Citr}^{3-}$ & $1:>200$ \\
$\mathrm{Fe}(\mathrm{III})$ & $1: 15$ & $\mathrm{Al}(\mathrm{III})$ & $1: 40$ & $\mathrm{Tart}^{2-}$ & $1:>200$ \\
$\mathrm{Mn}(\mathrm{II})$ & $1:>200$ & $\mathrm{Ba}(\mathrm{II})$ & $1:>200$ & $\mathrm{PO}_{4}{ }^{3-}$ & $1:>200$ \\
\hline
\end{tabular}

Table 3. Accuracy of the spectrophotometric determination of Pd(II) with ITHBA in model solutions, $n=3 ; \mathrm{P}=0.95$

\begin{tabular}{lccc}
\hline Content of matrix solution & $\begin{array}{c}\text { Added } \\
\text { Pd(II), } \\
\boldsymbol{\mu g}\end{array}$ & $\begin{array}{c}\text { Found Pd(II), } \\
\bar{x} \pm \frac{s \times t_{\alpha}}{\sqrt{n}}, \boldsymbol{\mu g}\end{array}$ & RSD, \% \\
\hline $0.48 \mathrm{mg} \mathrm{Pt}(\mathrm{IV}), 1.32 \mathrm{mg} \mathrm{Ni}(\mathrm{II}), 2.0 \mathrm{mg} \mathrm{Co}(\mathrm{II})$ & 24 & $23.6 \pm 1.0$ & 1.7 \\
$0.23 \mathrm{mg}$ Rh(III), $0.13 \mathrm{mg} \mathrm{Fe}(\mathrm{III}), 0.29 \mathrm{mg} \mathrm{Cu}(\mathrm{II})$ & 24 & $24.8 \pm 1.7$ & 2.8 \\
$0.04 \mathrm{mg} \mathrm{Ir}(\mathrm{IV}), 0.49 \mathrm{mg} \mathrm{Ag}(\mathrm{I}), 2.53 \mathrm{mg} \mathrm{Cd}(\mathrm{II})$ & 24 & $24.5 \pm 1.4$ & 2.3 \\
\hline
\end{tabular}

Table 4. Results of the determination of palladium(II) in the alloy, $n=3, \mathrm{P}=0,95$

\begin{tabular}{lccccc}
\hline & \multicolumn{2}{c}{ Spectrophotometry } & \multicolumn{2}{c}{ Voltammetry } \\
Intermetallides & $\omega_{P d}^{\text {calc }}, \boldsymbol{\%}$ & $\bar{\omega}_{P d}^{p r} \pm \frac{S \times t_{\alpha}}{\sqrt{n}}, \boldsymbol{\%}$ & $\mathbf{R S D , \%}$ & $\bar{\omega}_{P d}^{p r} \pm \frac{S \times t_{\alpha}}{\sqrt{n}}, \boldsymbol{\%}$ & RSD, \% \\
\hline $\mathrm{Yb}_{40} \mathrm{Pd}_{38} \mathrm{Sn}_{22}$ & 29.8 & $29.5 \pm 1.0$ & 1.4 & $30.2 \pm 0.8$ & 1.1 \\
$\mathrm{Yb}_{40} \mathrm{Pd}_{40} \mathrm{Ga}_{20}$ & 33.9 & $34.6 \pm 1.4$ & 1.6 & $34.3 \pm 0.6$ & 0.7 \\
\hline
\end{tabular}
$\ldots$ 
troduced-determined" method on model solutions. As it is shown in table 3 , the method has good reproducibility and accuracy of the determination.

In addition, the developed techniques of palladium spectrophotometric determination have been applied to palladium assay in the intermetallides and the resistor SP5-35B (table 4, 5).

Obtained data are in a good agreement with the content of palladium in the studied objects determined by voltammetric and atomic absorption spectroscopy methods (AAS), within the error of the photometric determination. Concomittant ions in the solutions did not affect the performed analyses.

Characteristics of some spectrophotometric methods for the determination of palladium are shown in table 6 .
Some of these methods are inferior in metrological characteristics to the method, which is proposed in this paper. The proposed technique unlike some presented in Table 6 does not need an organic solvent or highly acidic media, the reaction occurs immediately, the determination is not

Table 5. Results of the determination of palladium(II) in the resistor, $n=3, \mathrm{P}=0,95$

\begin{tabular}{lcc}
\hline Method & Found content Pd(II), & \\
& $\bar{x} \pm \frac{s \times t_{\alpha}}{\sqrt{n}}, \mathrm{mg}$ & RSD, \% \\
\hline AAS & $23.3 \pm 1.4$ & 2.5 \\
Spectrophotometry & $23.7 \pm 0.4$ & 0.7 \\
\hline
\end{tabular}

Table 6. Comparison of the present method with other spectrophotometric methods for the determination of palladium(II)

\begin{tabular}{|c|c|c|c|c|c|}
\hline Reagent & Conditions & $\lambda_{\max }$ & $\begin{array}{c}\varepsilon_{\max }, \\
\mathbf{L} \mathbf{m o l}^{-1} \mathbf{c m}^{-1}\end{array}$ & $\begin{array}{l}\text { Linear Range, } \\
\mu \mathrm{g} \mathrm{mL}\end{array}$ & $\begin{array}{l}\text { Interfering } \\
\text { ions }\end{array}$ \\
\hline Dimethylglyoxime $e^{4,7}$ & $\begin{array}{l}2 \mathrm{~mol} \mathrm{~L}^{-1} \mathrm{HCl} \text { or } \mathrm{H}_{2} \mathrm{SO}_{4} \\
\mathrm{CHCl}_{3} ; 0.8 \mathrm{~mol} \mathrm{~L}^{-1} \\
\mathrm{HNO}_{3}, \mathrm{pH}=1.0, \mathrm{CHCl}_{3}\end{array}$ & $\begin{array}{l}270 \\
370\end{array}$ & $\begin{array}{l}9.0 \times 10^{3} \\
1.9 \times 10^{3}\end{array}$ & $\begin{array}{l}25-125 \\
100-800\end{array}$ & $\begin{array}{l}\mathrm{Pt}(\mathrm{II}), \mathrm{Fe}(\mathrm{II}) \\
\mathrm{Ir}(\mathrm{III}), \mathrm{Au}(\mathrm{III})\end{array}$ \\
\hline $\begin{array}{l}\text {-Hydroxyacetophenone } \\
\text { thiosemicarbazone }\end{array}$ & $\begin{array}{l}\mathrm{pH}=6.0, \mathrm{H}_{2} \mathrm{O} \text { and } \\
\text { dimethylformamide }\end{array}$ & 370 & $9.0 \times 10^{3}$ & $0.4-10.6$ & $\mathrm{Fe}(\mathrm{III}), \operatorname{Ag}(\mathrm{I}), \operatorname{Sn}(\mathrm{II})$ \\
\hline 1-(2-Pyridylazo)-2-naphtol ${ }^{6}$ & $\begin{array}{l}\mathrm{pH}=1.5-7.5, \mathrm{CHCl}_{3}, \\
90^{\circ} \mathrm{C}\end{array}$ & 678 & $1.2 \times 10^{4}$ & $0.5-10$ & $\mathrm{Ni}(\mathrm{II}), \mathrm{Fe}(\mathrm{II}), \mathrm{Fe}(\mathrm{III})$ \\
\hline$\beta$-Nitroso- $\alpha$-naphthol ${ }^{7}$ & $\begin{array}{l}\mathrm{pH}=1.0-2.0, \mathrm{CHCl}_{3}, \\
\text { toluene }\end{array}$ & $308 ; 385 ; 370$ & $(2.1-2.2) \times 10^{4}$ & $1-5 ; 0.1-10$ & $\begin{array}{c}\mathrm{Cu}(\mathrm{II}), \mathrm{Co}(\mathrm{II}), \mathrm{Ni}(\mathrm{II}), \\
\mathrm{Cr}(\mathrm{III}), \mathrm{Fe}(\mathrm{III}), \mathrm{CN}^{-}\end{array}$ \\
\hline Palladiazo $^{7,8}$ & $\begin{array}{l}\mathrm{pH}=3.5 \\
n \text {-butanol }\end{array}$ & 640,675 & $5.7 \times 10^{4}$ & $0.2-5.0$ & $\begin{array}{c}\mathrm{Pb}(\mathrm{II}), \mathrm{Bi}(\mathrm{III}), \mathrm{Cl}^{-}, \\
\mathrm{REE}\end{array}$ \\
\hline $\begin{array}{l}\text { Sulphochlorophenolazo- } \\
\text { rhodanine }{ }^{9-12}\end{array}$ & $\begin{array}{l}8 \mathrm{~mol} \mathrm{~L}^{-1} \mathrm{H}_{3} \mathrm{PO}_{4}+ \\
+5 \mathrm{~mol} \mathrm{~L}^{-1} \mathrm{H}_{2} \mathrm{SO}_{4} ; \\
1 \mathrm{~mol} \mathrm{~L}^{-1} \mathrm{HCl}, 1-2 \mathrm{~h}\end{array}$ & $520 ; 520$ & $1.2 \times 10^{5} ; 5.0 \times 10^{4}$ & - & $\operatorname{Pt}(\mathrm{IV}), \mathrm{Rh}(\mathrm{III})$ \\
\hline 4-Phenylthiosemicarba-zide ${ }^{13}$ & Oleic acid surfactant & 300 & $4.9 \times 10^{3}$ & $2.0-4.5$ & - \\
\hline $\begin{array}{l}\text { 2-(2-Benzothiazolylazo)- } \\
\text { 5-dimethylamino-4- } \\
\text { tolylarsonic acid }\end{array}$ & $\begin{array}{l}\text { Sulphuric or nutric } \\
\text { acid and ethanol, } 10 \mathrm{~min}\end{array}$ & 718 & $6.7 \times 10^{4}$ & $0-1.6$ & - \\
\hline$\alpha$-Furildioxim ${ }^{7}$ & $0.1-1.4 \mathrm{~mol} \mathrm{~L}^{-1} \mathrm{HCl}, \mathrm{CHCl}_{3}$ & 380 & $2.2 \times 10^{4}$ & $1-3$ & - \\
\hline Dithizone $^{7,15}$ & $\mathrm{H}_{2} \mathrm{SO}_{4}, \mathrm{CCl}_{4}$ & 635 & $3.6 \times 10^{4}$ & to 4 & $\mathrm{Ag}(\mathrm{I}), \mathrm{Au}(\mathrm{III}), \mathrm{Cu}(\mathrm{II}), \mathrm{S}^{2-}$ \\
\hline Nitroso-R-salt ${ }^{7,16}$ & $\begin{array}{l}\mathrm{pH}=5.57 \text { to } 0.1 \mathrm{~mol} \mathrm{~L}^{-1} \\
\mathrm{HCl} ; 0.05 \mathrm{~mol} \mathrm{~L}^{-1} \mathrm{HNO}_{3}, \\
2.6 \mathrm{~N} \mathrm{CH}_{3} \mathrm{COOH}\end{array}$ & $\begin{array}{c}510 \\
520-560\end{array}$ & $\begin{array}{l}1.2 \times 10^{4} \\
9.7 \times 10^{4}\end{array}$ & $\begin{array}{l}1.3-4.3 \\
0.1-2.6\end{array}$ & $\mathrm{Co}(\mathrm{II}), \mathrm{Cl}^{-}$ \\
\hline $\begin{array}{l}\text { 4-(4'-Antipyriyl azo)- } \\
\text { 2-bromo phenol }{ }^{17}\end{array}$ & $\mathrm{pH}=4.0-7.0$ & 498 & $2.1 \times 10^{3}$ & $0.2-3$ & $\begin{array}{c}\mathrm{Cu}(\mathrm{II}), \mathrm{Co}(\mathrm{II}), \mathrm{V}(\mathrm{V}), \\
\mathrm{Ag}(\mathrm{I}), \mathrm{Fe}(\mathrm{III})\end{array}$ \\
\hline $\begin{array}{l}\text { 4-(2'-Furalideneimino)- } \\
\text { 3-methyl-5-mercapto- } \\
\text { 1,2,4-thiazole }\end{array}$ & $\mathrm{pH}=5.4, n$-butanol & 410 & $1.4 \times 10^{3}$ & $17-50$ & $\mathrm{Cu}(\mathrm{II}), \mathrm{Cr}(\mathrm{VI}), \mathrm{Mn}(\mathrm{VII})$ \\
\hline $\begin{array}{l}\text { Benzyloxybenzaldehyde- } \\
\text { thiosemicarbazone }^{19}\end{array}$ & $\mathrm{pH}=5.0$, cyclohexanol & 365 & $4.0 \times 10^{3}$ & $5-60$ & $\mathrm{Cu}(\mathrm{II})$ \\
\hline $\begin{array}{l}\text { Propionyl promazine } \\
\text { phosphate }^{20}\end{array}$ & $\mathrm{pH}=0.8-4.0$ & $490-500$ & $7.1 \times 10^{3}$ & $0.2-21$ & V(V), Ce(IV), Au(III) \\
\hline $\begin{array}{l}\text { 4-[N'-(4-Imino-2-oxo- } \\
\text { thiazolidin-5-ylidene)- } \\
\text { hydrazino]-benzene- } \\
\text { sulfonic acid }\end{array}$ & $\mathrm{pH}=7.6-8.3$ & 438 & $7.5 \times 10^{3}$ & $0.2-2.2$ & $\operatorname{Ir}(\mathrm{IV}), \mathrm{Ru}(\mathrm{IV})$ \\
\hline
\end{tabular}


interfered by many concomittant metals (Pt(IV), $\mathrm{Rh}(\mathrm{III})$, $\mathrm{Ni}(\mathrm{II}), \mathrm{Co}(\mathrm{II}), \mathrm{Cu}(\mathrm{II}), \mathrm{Fe}(\mathrm{III}), \mathrm{Ag}(\mathrm{I})$ etc.), sufficient sensitivity.

\section{Conclusions}

The spectrophotometric properties of ITHBA were researched and it was found out that this reagent forms a complex compound with Pd(II). A new simple method of spectrophotometric determination of palladium(II) ions with ITHBA, which is characterized by high selectivity, good sensitivity, reproducibility, accuracy and rapidness was elaborated. It is shown that this is a good method for the determination of palladium(II) when compared to some other spectrophotometric methods reported earlier. The proposed method has been successfully applied to the determination of palladium in intermetallides and resistor SP5-35B.

\section{References}

1. W. H. Guo, W. A. Brantley, W. A. T. Clark, J. Z. Xiao, E. Papazoglou, Dent. Mater. 2003, 19, 334-340. http://dx.doi.org/10.1016/S0109-5641(02)00063-5

2. D. B. Robinson et al., Int. J. Hydrogen Energy 2010, 35, 5423-5433.

http://dx.doi.org/10.1016/j.ijhydene.2010.03.031

3. Y. E. Zeng, H. S. Zhang, Z. H. Chen, Handbook of Modern Chemical Reagent, The Fourth Fascicule, Chromogenic Agent of Inorganic Ion, Chemical Industry Press, Beijing, P. R. China, 1989, p. 785

4. W. F. Davis, Talanta 1969, 16, 1330-1334. http://dx.doi.org/10.1016/0039-9140(69)80011-1

5. G. V. R. Murthy, T. S. Reddy, Talanta 1992, 39, 697-701. http://dx.doi.org/10.1016/0039-9140(92)80084-Q

6. J. Gao, B. Peng, H. Fan, J. Kang, X. Wang, Talanta 1997, 44, 837-842. http://dx.doi.org/10.1016/S0039-9140(96)02122-4

7. S. I. Ginzburg, N. A. Yezerskaya, I. V. Prokof'eva, N. V. Fedorenko, V. I. Shlenskaya, N. K. Belsky, Analiticheskaya Khimiya Platinovykh Metallov, Nauka, Moscow, Russia, 1972, p. 613.

8. J. A. Perez-Bustamante, F. Burriel-Martf, Anal. Chim. Acta 1967, 37, 49-61. http://dx.doi.org/10.1016/S0003-2670(01)80638-3

9. Ya. A. Zolotov, G. M. Varshal, V. M. Ivanov, Analiticheskaya Khimiya Metallov Platinovoi Gruppy, Editorial URSS, Moscow, Russia, 2003, p. 592.

10. S. B. Savvin, R. F. Gur'eva, Talanta 1987, 34, 87-101. http://dx.doi.org/10.1016/0039-9140(87)80012-7

11. R. F. Gur'eva, S. B. Savvin, Zh. Anal. Khim. 2002, 57, 1158-1175.

12. R. F. Gur' eva, S. B. Savvin, Usp. Khim. 1998, 67, 236-251. http://dx.doi.org/10.1070/RC1998v067n03ABEH000375
13. S. E. Ghazy, M. A. Kabil, A. A. El-Asmy, Y. A. Sherief, Anal. Lett. 1996, 29, 1215-1229. http://dx.doi.org/10.1080/00032719608001470

14. Lui Po, Lui Hegchuan, Wu Cheng, Talanta, 1991, 38, 11431146. http://dx.doi.org/10.1016/0039-9140(91)80233-P

15. Z. Marczenko, S. Kus', Analyst 1985, 110, 1005-1008. http://dx.doi.org/10.1039/an9851001005

16. J. Shamir, A. Schwartz, Talanta 1961, 8, 330-332. http://dx.doi.org/10.1016/0039-9140(61)80090-8

17. H. J. Mohammed, A. Y. Muhi, H. Al. Meisslemaw, E-J. Chem. 2011, 8, 425-433.

18. S. H. Gaikwad, T. N. Lokhande, M. A. Anuse, Indian J. Chem. A 2005, 44, 1625-1630.

19. S. L. Narayana, K. J. Reddy, S. A. Narayana Reddy, J. R. Kumar, A. V. Reddy, J. Chin. Chem. Soc. 2007, 54, 1233-1241.

20. B. Keshavan, P. Nagaraja, Microchem. J. 1985, 31, 124-129. http://dx.doi.org/10.1016/0026-265X(85)90019-0

21. L. Lozynska, O. Tymoshuk, Chemistry \& Chemical Technology 2013, 7, 391-395.

22. L. Lozynska, O. Tymoshuk, In: O. L. Berezko, The Interaction of 5-hydroxyimino-4-imino-1,3-thiazolidin-2-one with Platinum(IV) Ions, $3^{\text {rd }}$ International Conference of Young Scientists CCT-13, Lviv, Ukraine, 2013, 166.

23. L. V. Lozynska, O. S. Tymoshuk, T. I. Chaban, Methods and Objects of Chemical Analysis 2014, 9(1), 50-54.

24. L. V. Lozynska, O. S. Tymoshuk, Visnyk of the Lviv University. Series Chemistry 2014, 55

25. R. S. Lebedev, Russ. Phys. J. 2002, 45, 822-830. http://dx.doi.org/10.1023/A:1021928817028

26. D. Kaminskyy, B. Zimenkovsky, R. Lesyk, Eur. J. Med. Chem. 2009, 44, 3627-3636. http://dx.doi.org/10.1016/j.ejmech.2009.02.023

27. L. Mosula, B. Zimenkovsky, D. Havrylyuk, A.-V. Missir, I. Cornelia Chirita, R. Lesyk, Farmacia 2009, 57, 321-330.

28. I. D. Komaritsa, Chem. Heterocycl. Compd. 1968, 4, 324325. http://dx.doi.org/10.1007/BF00755270

29. Yu.Yu. Lur'e, Spravochnik po analiticheskoi khimii, Khimiya, Moscow, Russia, 1971, p. 456. 


\section{Povzetek}

Raziskovali smo spektrofotometrične lastnosti novega, prvič sintetiziranega reagenta - 4-[N'-(4-imino-2-okso-tiazolidin-5-iliden)-hidrazino]-benzensulfonske kisline (ITHBA). Razvili smo preprosto, hitro, točno, selektivno in občutljivo metodo za spektrofotometrično določitev Pd(II) ionov z uporabo tega reagenta. Poiskali smo optimalne pogoje za tvorbo kompleksa. Molarna absorptivnost pri $\lambda=438 \mathrm{~nm} \mathrm{je} 7,5 \times 10^{3} \mathrm{~L} \mathrm{~mol}^{-1} \mathrm{~cm}^{-1}$, Beerov zakon velja za koncentracije med 0,2-2,2 $\mu \mathrm{g} \mathrm{mL} \mathrm{m}^{-1} \mathrm{Pd}(\mathrm{II})$. Raziskovali smo vpliv drugih ionov. Metoda se je izkazala za uspešno pri določevanju paladija $\mathrm{v}$ intermetalidih in uporih. Točnost spektrofotometrične metode za paladij z 4-[N'-(4-imino-2-okso-tiazolidin-5iliden)-hidrazino]-benzensulfonsko kislino $\mathrm{v}$ realnih vzorcih smo potrdili z voltametrično ali atomsko absorpcijsko spektroskopsko metodo. 